\author{
ZBIGNIEW ZAGÓRSKI ${ }^{1 *}$, MONIKA KISIEL ${ }^{2}$ \\ ${ }^{1}$ Warsaw University of Life Sciences - SGGW, Faculty of Agriculture and Biology, Department of Soil Environment Sciences \\ Nowoursynowska Str. 159, 02-776 Warsaw, Poland \\ ${ }^{2}$ Cardinal Stefan Wyszyński University in Warsaw, Faculty of Biology and Environmental Sciences, \\ Department of Environmental Engineering \\ Wóycickiego Str. 1/3, 01-938 Warsaw, Poland
}

\title{
Forms of iron in parent rocks of soils developed from Lower Triassic (Buntsandstein) deposits in the NE part of the Holy Cross Mountains (Poland)
}

\begin{abstract}
The aim of the study was to characterize pedogenic iron forms in the sediments of the Lower Triassic (Buntsandstein) in the north-eastern part of the Holy Cross Mountains. These are sediments of continental origin and unique features as the so-called 'red beds'. Three main types of rocks were studied - sandstones, mudstones and claystones. Chemical forms of iron: $\mathrm{Fe}_{t}$ (XRF), $\mathrm{Fe}_{\mathrm{HCl}}(6 \mathrm{M} \mathrm{HCl}), \mathrm{Fe}_{\mathrm{d}}$ (dithionite-citrate-bicarbonate, $\mathrm{DCB}$ ), $\mathrm{Fe}_{\mathrm{o}}$ (ammonium oxalate), $\mathrm{Fe}_{\mathrm{p}}$ (sodium pyrophosphate) were determined. The XRD method revealed the occurrence of goethite in sandstones and hematite in mudstones and claystones. Differential XRD (DXRD) analysis did not show the presence of amorphous iron minerals. The average $\mathrm{Fe}_{\mathrm{t}}$ content in sandstones was $83 \mathrm{~g} \cdot \mathrm{kg}^{-1}$, in mudstones $47 \mathrm{~g} \cdot \mathrm{kg}^{-1}$, in claystones $55 \mathrm{~g} \cdot \mathrm{kg}^{-1}$, while there were lower concentrations of $\mathrm{Fe}_{\mathrm{d}}\left(66 \mathrm{~g} \cdot \mathrm{kg}^{-1}, 13 \mathrm{~g} \cdot \mathrm{kg}^{-1}, 26 \mathrm{~g} \cdot \mathrm{kg}^{-1}, \mathrm{respec}-\right.$ tively). $\mathrm{Fe}_{\mathrm{o}}$ form content was in the range of $0.3-4 \mathrm{~g} \cdot \mathrm{kg}^{-1}$, while there were only traces of $\mathrm{Fe}_{\mathrm{p}}$. Only $\mathrm{Fe}_{\mathrm{t}}$ and $\mathrm{Fe}_{\mathrm{HCl}}$ occurred in good correlation. In the pedogenic interpretation of the studied rocks, mutual relations between chemical forms of iron were used and their reference to the identified iron minerals. Siltstones and claystones have high resistance to pedogenic factors, which is indicated by low release rates $\mathrm{Fe}_{\mathrm{d}}: \mathrm{Fe}_{\mathrm{t}}$ and very low amorphization index $\mathrm{Fe}_{\mathrm{o}}: \mathrm{Fe}_{\mathrm{d}}$. The reason is the presence of well crystalline hematite in these rocks. In sandstones, resistance is conditioned by the occurrence of goethite in the matrix. Chemical destruction of iron-carbonate cement promotes the release and amorphization of iron in soils developed from sandstones. The presented results indicate that the specificity of Lower Triassic rocks is important for the proper classification and assessment of properties of soils with a characteristic red colour.
\end{abstract}

Keywords: iron forms, hematite, goethite, parent rocks, Triassic (Buntsandstein)

\section{INTRODUCTION}

The content of iron and its distribution in soil is an important issue for soil science. Numerous authors studying soils in various climate zones indicate that the presence of iron, aluminium and manganese in the soil substrate, and the distribution of these elements in the soil profile may also depend on the origin of the parent rock (Schwertmann and Taylor 1989; Torrent et al. 1980, Costantini et al. 2006, Stucki et al. 2012). Iron compounds are highly important for pedogenic processes. Numerous studies point to a strict relationship between the occurrence of various $\mathrm{Fe}$ forms and pedogenic processes (Schwertmann 1988, Lesovaya et al. 2005, Vodyanitskii 2010). The relationships that occur between the content of total, free, and amorphous iron are the basis for the description of many processes shaping soil properties (MacKeague and Day 1966; Zagórski 2001, Różański et al. 2013). Mutual ratios calculated between different $\mathrm{Fe}$ forms are useful proxies for determining the soil type and origin. They are taken into account in current soil classifications and systematics, e.g. the Polish Soil Classification (2011) and the World Reference Base for Soil Resources (IUSS Working Group WRB 2015). In some cases the content of iron in parent rock may be very high. This is the effect of various geological processes: sedimentary (e.g. in the case of desert facies), diagenetic (presence of $\mathrm{Fe}$ neoformations) or specific types of weathering (e.g. formation of laterites) (Curi and Franzmeier 1987; Zagórski and Kaczorek 2002). Usually such rocks have characteristic features, i.e. they are red or orangecoloured (Torrent and Schwertmann 1986). Such strata are generally referred to as the 'red beds' (Walker 1968, Van Houten 1973). Soils developed from such rocks are typified by their morphological separateness, and specific physical and chemical properties (Lesovaya et al. 2005, Vodyanitskii et al. 2003, Zagórski et al. 2015). In Poland, these issues refer particularly to soils developed from Lower Triassic rocks in the Holy Cross Mountains area. 
In this region, depending on the local geological setting, Lower Triassic strata outcrop over vast areas as complexes of red sandstones, siltstones and claystones. Smaller, local occurrences of these rocks are known also in the vicinity of strata with a different geological history and age, e.g. Palaeozoic or Jurassic limestones, or Quaternary tills and loesses (Senkowiczowa and Ślączka 1962).

So far, studies performed in the Holy Cross Mountains area indicate that the properties of soils developed from Triassic deposits largely depend on the lithology of the parent rock (sandstones, siltstones or claystones) (Zagórski and Kaczorek 2002; Brzychcy and Zagórski 2009; Zagórski and Kisiel 2010, 2014; Zagórski et al. 2015). Results of field macroscopic observations and obtained analytical data for the soil substrate should be verified very carefully with regard to primary features inherited from the parent rock. Thus, the study of various types of Lower Triassic rocks with regard to the transformations they subjected during pedogenic processes is an important issue. The purpose of the present study is determination of the chemical and mineralogical characteristics of $\mathrm{Fe}$ compounds from the Buntsandstein (Lower Triassic) deposits which are parent rocks for soils in the north-eastern part of the Holy Cross Mountains area. The study should enable determining the susceptibility of the mineral components of Triassic rocks, particularly iron minerals, to pedogenic processes. So far, data in this topic are lacking. The obtained results will be crucial for a better recognition of the origin and properties of soils developed from Lower Triassic rocks.

\section{MATERIALS AND METHODS}

Location of the study area

The studies were performed in north-eastern part of the Holy Cross Mountains area, in the marginal zones of the Kamienna, Kamionka and Świślina river valleys, where clastic Lower Triassic deposits are developed in the Buntsandstein facies (Fig. 1). Detailed studies were performed in representative sites located near Czerwona Góra, Dziurów, and Wąchock (Fig. 1). Each locality represents one of the three main lithological types of the Lower Triassic sandstones, siltstones and claystones. Sequences with lithological uniformity were selected, i.e. significant admixtures of material from the neighbourhood (such as Quaternary sands or loesses) were not observed in them. Detailed observations and analyses have been performed on deposits that may act as direct parent rock for soils. It was assumed that these rocks are transformed into the soil substrate in the course of pedogenic processes. Samples for investigations presented herein were collected from the lowermost genetic soil horizon, i.e. parent rock ( $\mathrm{C}$ horizon), where typical lithological features were recorded. Ten samples were taken from each soil pit. Chemical analyses was carried out in duplicate for each sample. Main features and properties of the studied parent rocks are presented in Table 1.

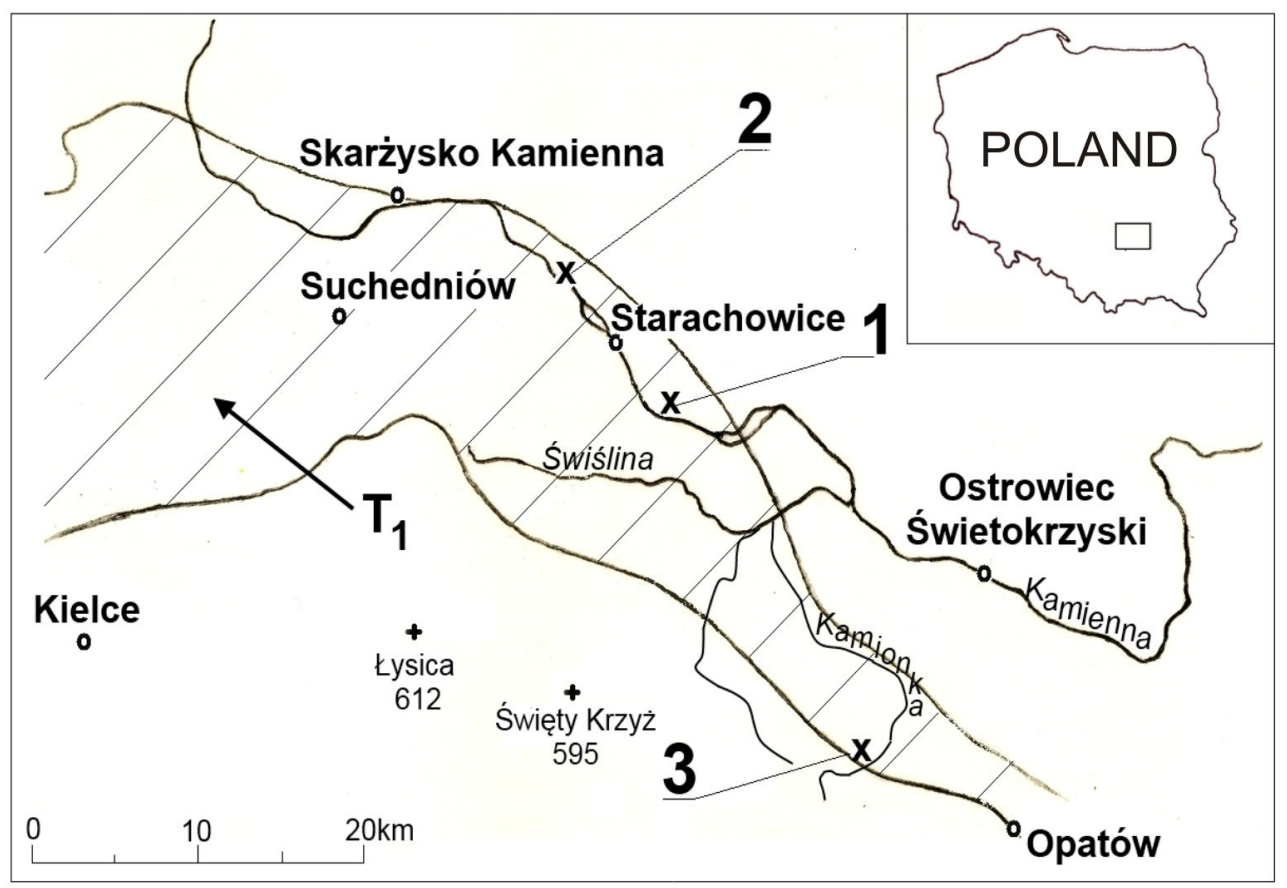

FIGURE 1. Location of study sites: 1 - Dziurów (D1), 2 - Wąchock (W1), 3 - Czerwona Góra (CG3).

The occurrence of Lower Triassic sediments $\left(\mathrm{T}_{1}\right)$ in the area of the NE Holy Cross Mountains according to Wyszomirski and Muszyński (2007) 


\section{Geological setting}

The study area is located within a large structural unit known as the north-eastern Mesozoic Margin of the Holy Cross Mountains (Senkowiczowa 1966). In this area, Lower Triassic Buntsandstein deposits occur in a narrow belt up to several kilometres wide between Opatów, Starachowice and Bodzentyn towns. In the north-western part they comprise the uppermost member of the Buntsandstein (so-called Röt), whereas the lower and middle Buntsandstein occurs in the south-eastern part (Samsonowicz 1932, Filonowicz 1968, Studencki 1993). The deposits comprise continental facies formed within vast floodplains of low-velocity braided rivers. Coarser strata gravels and sands - were developed in channel zones, whereas silts and clays developed within floodplains. It is also possible that some fine-grained deposits, e.g. the Röt clays, developed as playa facies. Lower Triassic rocks usually attain a characteristic red colour, which is related to the presence of large amounts of $\mathrm{Fe}$ oxides. This is obviously the effect of specific climate conditions that prevailed during the Early Triassic, determined as extremely continental (Barczuk 1979, Mader and Barczuk 1985). Thus, they fulfil the criteria of facies assigned to red beds.

In majority of the study area, Lower Triassic strata are covered by a thin layer of Quaternary sediments (mainly loesses or rarely post-glacial sands). They are exposed directly on the surface only on the ridges of some structural highs, and on the slopes of the Kamienna, Kamionka and Świślina river valleys, local erosional cuts or artificial exposures.

\section{Study sites and exposures}

\section{Czerwona Góra (CG) study site}

The area is located in the eastern part of the study area, near Czerwona Góra village (Fig. 1). Orange sandstones with interbeds of fine-grained conglomerates, assigned to the middle part of the Buntsandstein, occur along the slopes of Kamionka river valley. According to Mader and Barczuk (1985), the rocks represent fluvial deposits of the Czerwona Góra Beds. Exposure CG3 is located on the southern valley margin where the steep slope is incised by a road excavation (Fig. 2a). The exposure shows the presence of thin-bedded, yellow-orange coloured sandstones. Macroscopically they include semiloose, fine-grained, polymictic sandstones with an iron oxide-carbonate matrix. Reaction with $\mathrm{HCl}$ indicates that the content of carbonates is about $2-3 \%$. The sandstones are overlain by $0.5-1.0 \mathrm{~m}$ thick, light red coloured (10R 6/6) (Munsell Soil Color Charts 2009) erosional clay residuum with a large amount of sandstone fragments. This is the parent rock for the developing soils. Soils with an ABw-C-R profile, assigned to brown rankers (Polish Soil Classification 2011) or to Chromic Cambic Leptosols (Loamic, Skeletic) (IUSS Working Group WRB 2015) occur in the vicinity of this exposure.
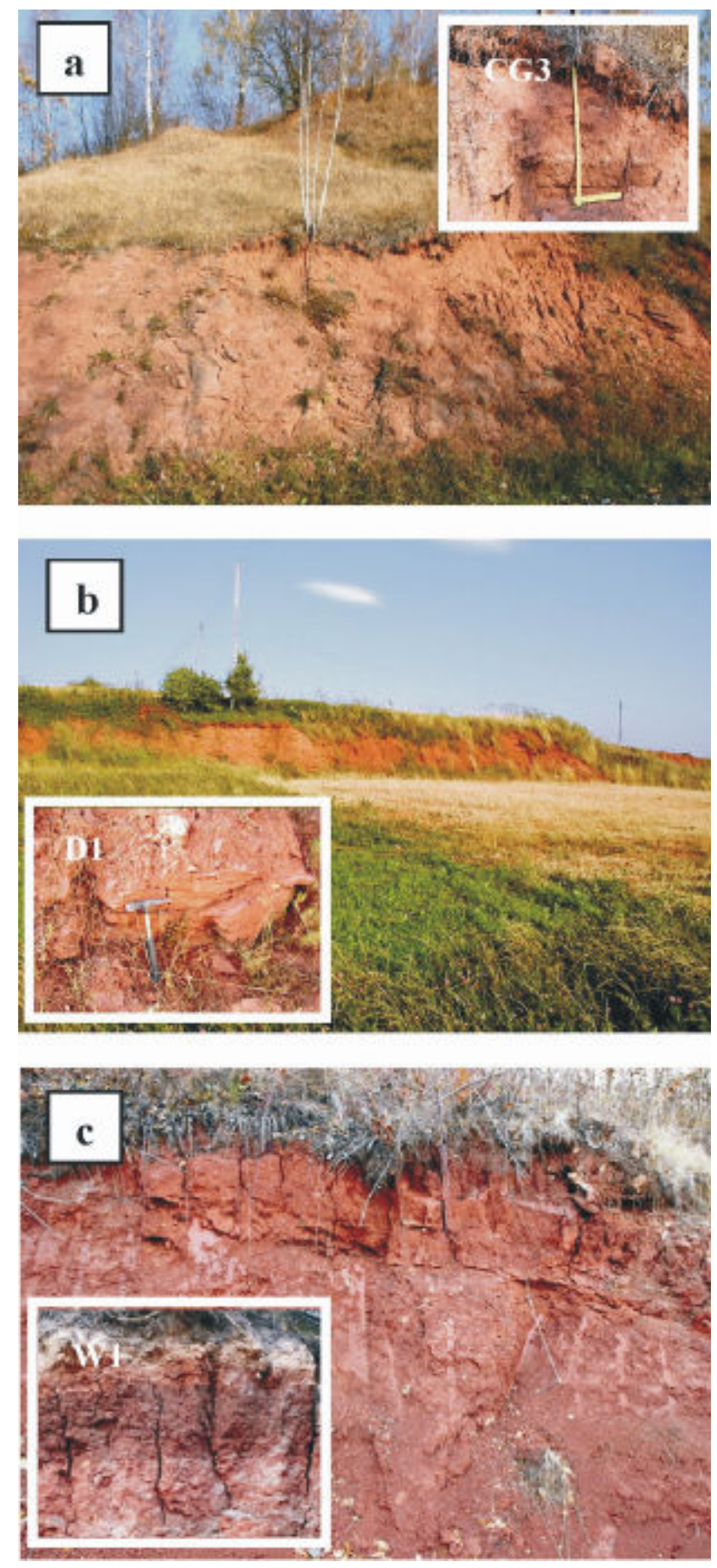

FIGURE 2. Outcrops of Lower Triassic sediments (Buntsandstein) in NE Holy Cross Mountains: a - Czerwona Góra - sandstones, b - Dziurów - siltstones, c - Wąchock - claystones. CG3, D1, $\mathrm{W} 1$ - analyzed exposures 


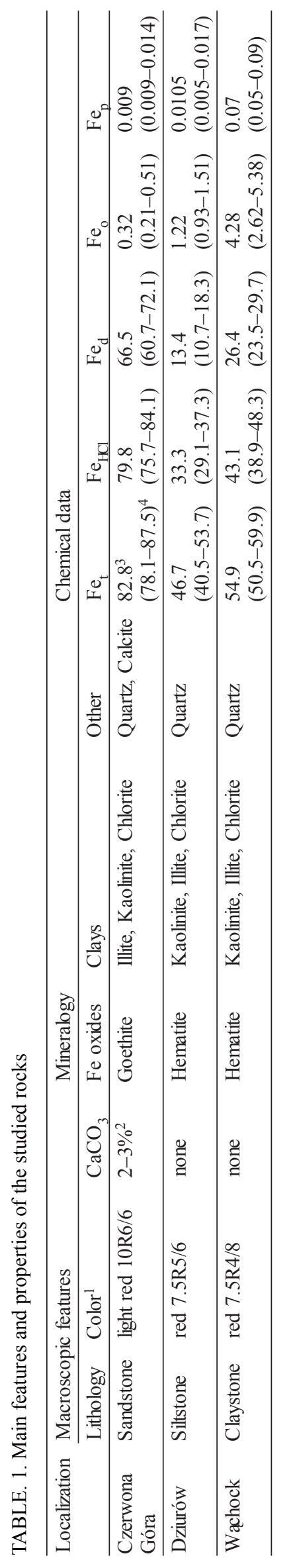

\section{Dziurów (D) study site}

This region is characterised by red deposits occurring on the gentle, northern slopes of Kamienna river valley between Starachowice town and Dziurów village. The strata include siltstones with interbeds of sandstones, composing the Upper Buntsandstein - Röt (Studencki 1993). Exposure D1 is located in the eastern part of Dziurów village (Fig. 2b). Erosional escarpments of a small dry valley expose thin-bedded red siltstones $(10 \mathrm{R} 5 / 8)$. These strata are overlain by a reddish brown erosional clay-silt cover (2.5YR 4/5), containing a small admixture of sand and small fragments of siltstones. Such erosional cover is the parent rock for the soils in the vicinity of Dziurów. The most common soils in this area are typical dystrophic brown soils (Polish Soil Classification 2011) with a succession of genetic horizons A-Bw-C or A-BwC-C. According to the WRB (IUSS Working Group WRB 2015) criteria they may be assigned to Chromic Leptic Cambisols (Clayic).

\section{Wąchock (W) study site}

Deposits typical for the lower part of the southern slopes of the Kamienna river valley, to the east of Wachock, occur in this area. They include claystones and siltstones belonging to the Upper Buntsandstein (Röt) represented by the Wąchock Beds (Studencki 1993). The Wąchock 1 (W1) exposure is situated within a steep slope, additionally undercut by an escarpment created by construction works (Fig. 2c). The exposure yields several tens of centimetres thick levels of red claystones (10R 4/8). Close to the surface, the rocks undergo mechanical destruction and create a clayey soil substrate, red (10R 4/8) or dark red "cherry" (7.5R 3/6) in colour. Brown soils with an A-BwC-C/R profile (Polish Soil Classification 2011) occur in the vicinity of this exposure. According to WRB (IUSS Working Group WRB 2015), they can be assigned to Chromic Cambic Leptosols (Clayic).

\section{Analytical methods}

\section{Studies of iron minerals were conducted using}

X-ray diffraction (XRD) method by means of a Bruker/AXS D-5005 apparatus. CoK $\alpha$ radiation was used with the applied voltage of $40 \mathrm{kV}$ and $35 \mathrm{~mA}$ current. The determinations were made for powdered, non-oriented samples (after drying and grinding to a fraction below $0.1 \mathrm{~mm}$ ). The qualitative identification of Fe minerals was based on $\mathrm{d}_{\mathrm{hkl}}$ values of characteristic reflexes compared with standard data (Brindley and Brown 1980; Cornell and Schwertmann 2006). The precise identification of Fe minerals was made using differential XRD (DXRD) technique. Differential XRD patterns were obtained by comparison of XRD patterns for raw samples with XRD patterns for samples subjected to dithionite-citrate-bicarbonate $\left(\mathrm{DXRD}_{\mathrm{DCB}}\right)$ or ammonium oxalate extraction $\left(\mathrm{DXRD}_{\mathrm{ox}}\right)($ Schulze 1981, 1994; Campbell and Schwertmann 1985). Best fitting of XRD patterns was maintained by coefficient $\mathrm{k}$ calculated separately for each sample (Schulze 1981). Beside iron minerals, the XRD method allowed to identify other minerals, e.g. primary minerals or clay minerals.

Laboratory analyses were focused on determining the content of various chemical Fe forms applied in soil science (MacKeague et al. 1971, Zagórski 2001) and identification of iron minerals (Stucki et. al 2012 ). The analyzed iron forms are listed in Table 2 . The content of total iron $\left(\mathrm{Fe}_{t}\right)$ was determined using the WD-XRF method by means of a PW 2400 (Philips) 
TABLE 2. Chemical types of iron forms determined in various rocks of the Buntsandstein formation in the NE Holy Cross Mountains

\begin{tabular}{lll}
\hline Iron form & $\mathrm{Symbol}$ & Method \\
\hline Total (XRF) & $\mathrm{Fe}_{\mathrm{t}}$ & Beckhoff et al. (2007) \\
\hline Dissolved in $\mathrm{HCl}$ & $\mathrm{Fe}_{\mathrm{HCl}}$ & Gedrojć (1955) \\
\hline Free & $\mathrm{Fe}_{\mathrm{d}}$ & $\begin{array}{l}\text { Mehra and Jackson (1960), } \\
\text { Pansu and Gautheyrou (2006) }\end{array}$ \\
\hline Amorphous & $\mathrm{Fe}_{\mathrm{o}}$ & $\begin{array}{l}\text { Tamm (1924), Pansu and } \\
\text { Gautheyrou (2006) }\end{array}$ \\
\hline $\begin{array}{l}\text { Bound in organic } \\
\text { complexes }\end{array}$ & $\mathrm{Fe}_{\mathrm{p}}$ & $\begin{array}{l}\text { Loveland and Digby (1984), } \\
\text { Pansu and Gautheyrou (2006) }\end{array}$ \\
\hline
\end{tabular}

apparatus in the Central Chemical Laboratory of the Polish Geological Institute - National Research Institute (CCHL PIG-PIB). The content of iron in the remaining forms $\left(\mathrm{Fe}_{\mathrm{HCl}}, \mathrm{Fe}_{\mathrm{d}}, \mathrm{Fe}_{\mathrm{o}}\right.$ and $\left.\mathrm{Fe}_{\mathrm{p}}\right)$ was determined by extraction of $\mathrm{Fe}$ using proper reagents followed by the determination of $\mathrm{Fe}$ contents in extracts by means of atomic absorption spectroscopy (AAS) method using a Solar M6 Thermo Elemental apparatus in the Department of Soil Environment Sciences, Warsaw University of Life Science SGGW, Poland.

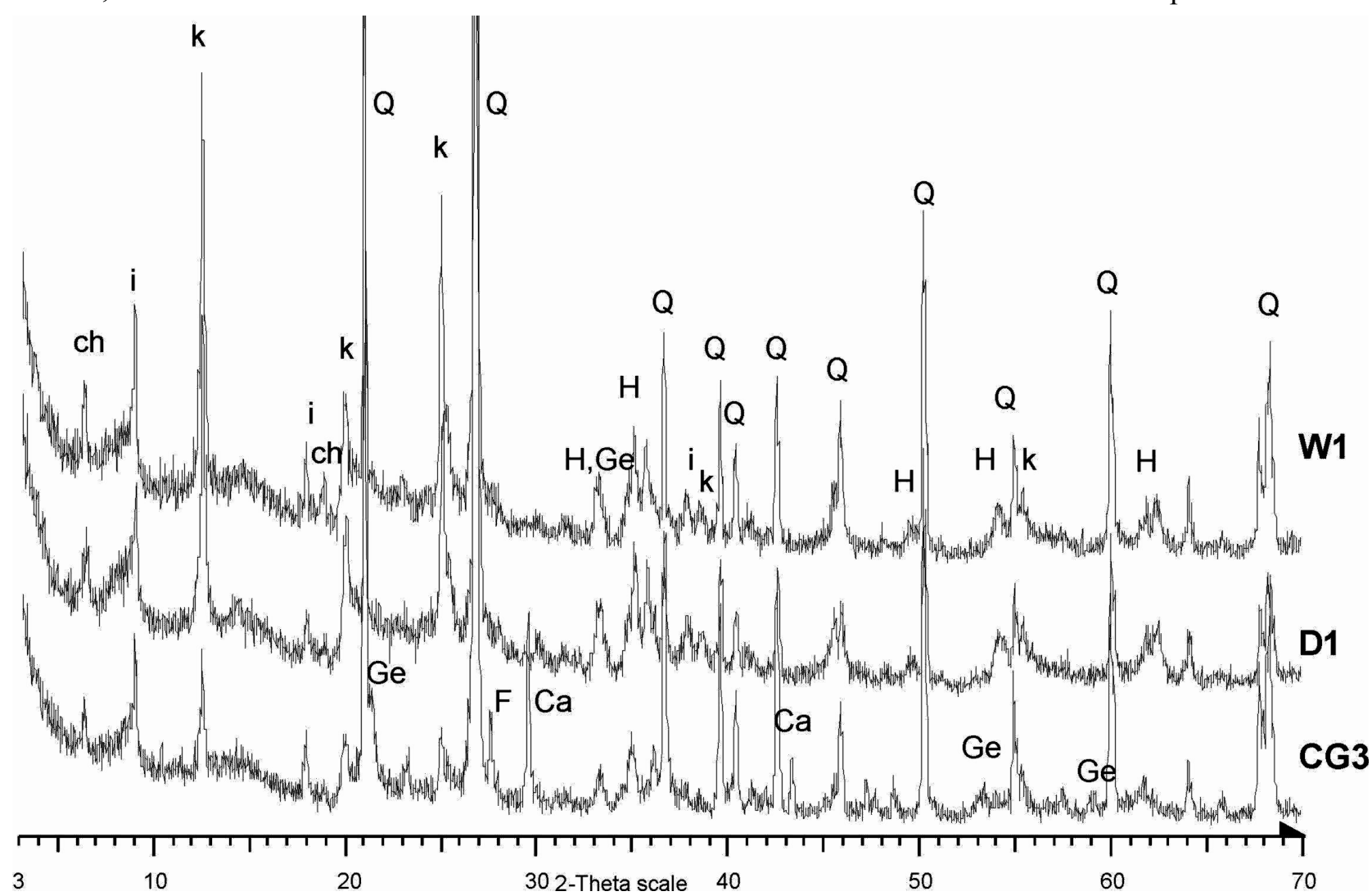

\section{RESULTS}

\section{Mineralogical iron forms}

The mineral composition of the studied rocks depends on their lithology. Based on XRD (Fig. 3), all rocks studied have a similar assemblage of rockforming minerals - quartz, clay minerals, and iron minerals. Depending on the petrography of the rock, there were significant differences in the quantitative contribution of particular minerals. Sandstones from CG3 and siltstones from D1 are dominated by quartz, whereas clay minerals prevail in claystones from W1. Additionally, sandstones from CG3 contain an admixture of feldspars and small amounts of calcite (Fig. 3). Among the clay minerals, there is a distinct difference between rocks representing the Middle Buntsandstein and the Röt. Sandstones from CG3 yield a relatively levelled quality composition of clay minerals represented by illite, kaolinite, and chlorite. A characteristic feature of siltstones and claystones is the domination of kaolinite at subordinate contribution of illite and chlorite (Fig. 3).

A particular feature of the mineral composition of all Lower Triassic rocks studied is the presence of $\mathrm{Fe}$

FIGURE 3. Mineralogical composition of the various rocks of the Buntsandstein formation in the NE Holy Cross Mountains: W1 claystone, D1 siltstone, CG3 sandstone; XRD patterns of powder samples $<0.1 \mathrm{~mm}$. Symbols of minerals: $\mathrm{H}-$ hematite, $\mathrm{Ge}$ - goethite, Q - quartz, Ca - calcite, F -feldspar, $\mathrm{k}$ - kaolinite, i - illite, ch - chlorite 
compounds. Their qualitative characteristics was investigated following the research goal. The basis of this characteristics was XRD analysis. Sandstones from Czerwona Góra contained goethite, which is evidenced by $\mathrm{d}_{\mathrm{hkl}}$ reflexes of $4.16 \AA, 2.25 \AA, 1.71 \AA$ and $1.50 \AA$ on the XRD patterns (Fig. 3). The main iron mineral in claystones from Wąchock and siltstones from Dziurów is hematite, as indicated by $\mathrm{d}_{\mathrm{hkl}}$ reflexes of $2.69 \AA 2,2.51 \AA, 1.83 \AA, 1.69 \AA 2,1.48 \AA$ and $1.44 \AA$.

A crucial issue in the studies of Fe minerals in sedimentary rocks and in soils is the identification of minerals with poorly crystalline structures, such as ferrihydrite or schwertmannite (Vithana et al. 2015). In the case of the studied rocks, additional differential $\mathrm{X}$-ray diffraction (DXRD) was used to check the presence of these minerals. In the $\mathrm{DXRD}_{\mathrm{DCB}}$ patterns (Fig. 4) for the samples studied, the reflexes point to the presence of hematite in $\mathrm{W} 1$ claystones and D1 siltstones, as well as goethite in CG3 sandstones. Comparison of XRD patterns performed on these samples before and after extraction with ammonium oxalate indicates good crystallinity of hematite and goethite. There were no reflexes pointing to the presence of poorly crystalline Fe minerals, e.g. ferrihydrite, in the DXRD ox patterns (Fig. 5).

Among minerals that are not $\mathrm{Fe}$ minerals but contain iron in their structure, chlorites are worth noting. Their presence was noted in XRD analysis (Fig. 3). Easily undergoing weathering, chlorite plays an important role as a proxy of pedogenic processes. In this context, comparison of $\mathrm{DXRD}_{\text {ox }}$ patterns gave an interesting result. A distinct attenuation of the 001 reflex of chlorite (ca. 14£) was observed (Fig. 6). This indicates that the structure of chlorite underwent partial destruction. Most probably the reason was removal of iron from the crystalline network during extraction by ammonium oxalate, which as a consequence led to the partial decomposition of this mineral (Ross 1968, Hamer et al. 2003).

\section{Chemical iron forms}

The content of individual iron forms in the studied rock types is presented in Figure 7. The highest content of total iron $\left(\mathrm{Fe}_{\mathrm{t}}\right)$ was noted in sandstones from CG3 - between $78-87 \mathrm{~g} \cdot \mathrm{kg}^{-1}$, averagely 83 $\mathrm{g} \cdot \mathrm{kg}^{-1}$ (Fig. 7). In other rocks, the total iron content was ower. In siltstones $\mathrm{W} 1$, the total iron content was between $40-53 \mathrm{~g} \cdot \mathrm{kg}^{-1}$, whereas in claystones $\mathrm{W} 1$ it was between $50-60 \mathrm{~g} \cdot \mathrm{kg}^{-1}$.

A different distribution was observed in the case of free iron $\left(\mathrm{Fe}_{\mathrm{d}}\right)$ (Fig. 7). In siltstones D1 the free iron content was relatively high (about $68 \mathrm{~g} \cdot \mathrm{kg}^{-1}$ ), whereas in the remaining rocks, the content of free iron was much lower - about $16 \mathrm{~g} \cdot \mathrm{kg}^{-1}$ in claystones $\mathrm{W} 1$ and only about $13 \mathrm{~g} \cdot \mathrm{kg}^{-1}$ in siltstones D1. The content of amorphous iron $\left(\mathrm{Fe}_{\mathrm{ox}}\right)$ in the rocks studied did not show a quantitative relationship with the distribution of the Fe forms mentioned above and

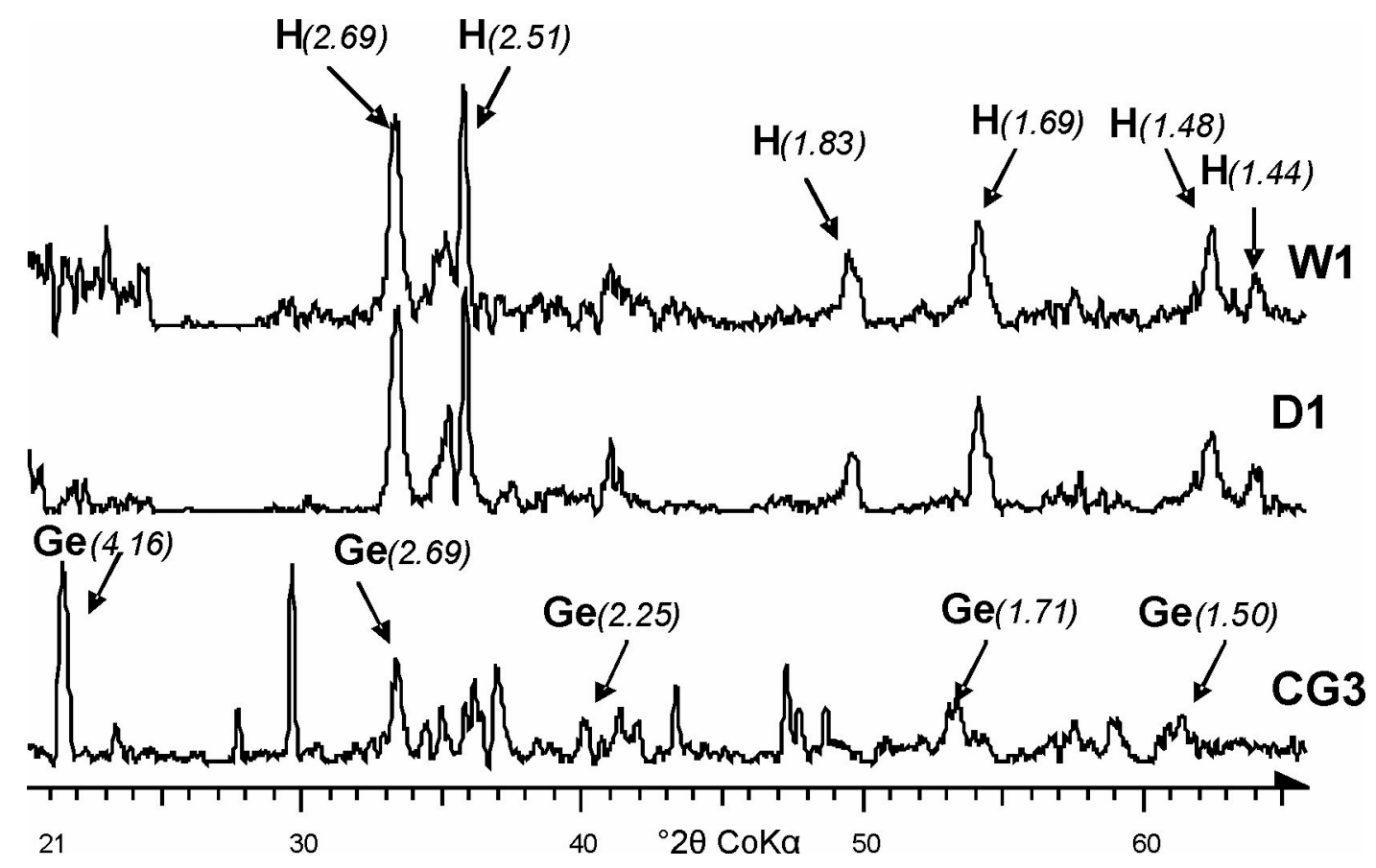

FIGURE 4. Identification of iron minerals in various rocks of the Buntsandstein formation in the NE Holy Cross Mountains: W1 claystone, D1 siltstone, CG3 sandstone. DXRD patterns after treatment with DCB. Symbols of minerals: $\mathrm{H}$ - hematite, Ge goethite. (2.25) $-d$ spacing in $\AA$. 


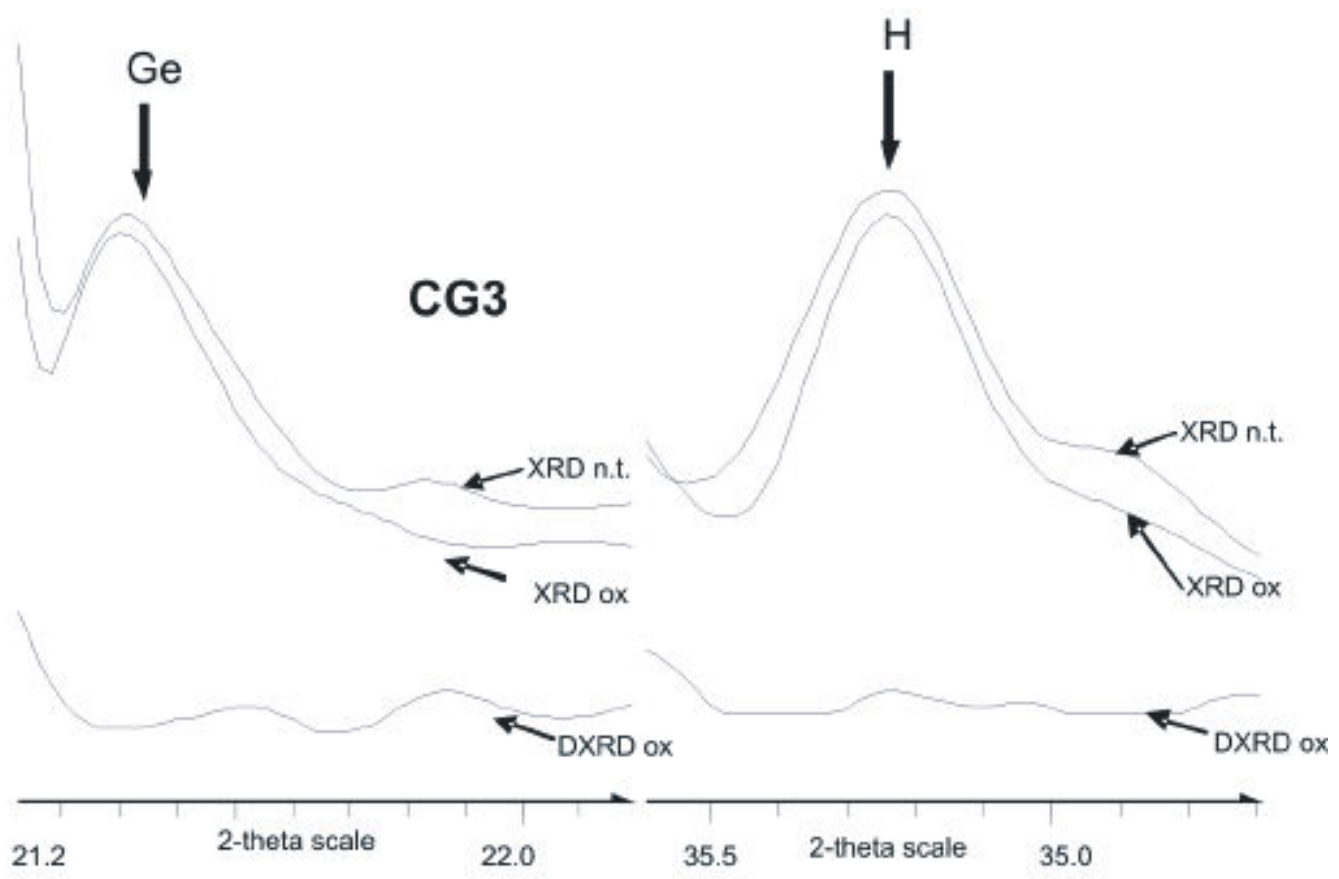

FIGURE 5. Effect of ammonium oxalate treatment on iron oxide mineralogy taking CG3 sample as an example. XRD patterns show no reaction of goethite and hematite. Abbreviations: n.t. - not treated

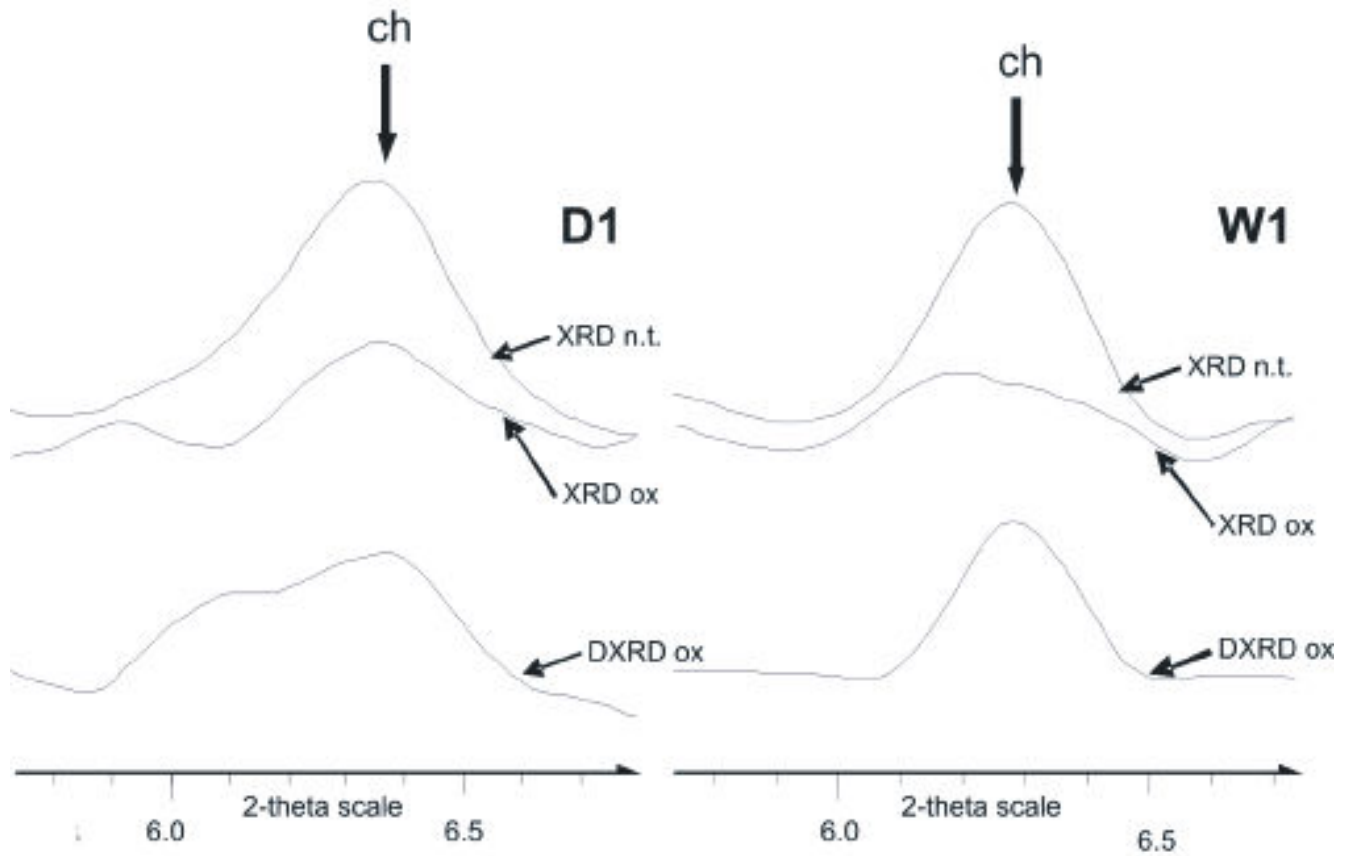

FIGURE 6. Effect of ammonium oxalate treatment on mineralogy of clay fraction. XRD patterns show a partial destruction of the chlorite structure

Abbreviations: W1 - claystone, D1- siltstone, n.t. - not treated

generally was at a much lower level (Fig. 7). The content of $\mathrm{Fe}_{\mathrm{ox}}$ was very low in sandstones CG3 only about $0.3 \mathrm{~g} \cdot \mathrm{kg}^{-1}$ on average. In siltstones D1, $\mathrm{Fe}_{\text {ox }}$ content was relatively higher - about $1.2 \mathrm{~g} \cdot \mathrm{kg}^{-1}$. The highest contribution of amorphous iron was noted in claystones $\mathrm{W} 1-4.29 \mathrm{~g} \cdot \mathrm{kg}^{-1}$ on average, however with the largest variability of the results - from $2.62 \mathrm{~g} \cdot \mathrm{kg}^{-1}$ to $5.38 \mathrm{~g} \cdot \mathrm{kg}^{-1}$. In the rocks studied, the content of iron bound with organic matter $\left(\mathrm{Fe}_{\mathrm{p}}\right)$ was extremely low, from $0.01 \mathrm{~g} \cdot \mathrm{kg}^{-1}$ (D1, CG3) to $0.07 \mathrm{~g} \cdot \mathrm{kg}^{-1}$ (W1) (Fig. 7), therefore this form has a trace contribution.

Large difference between the content of free iron $\left(\mathrm{Fe}_{\mathrm{d}}\right)$ and total iron $\left(\mathrm{Fe}_{\mathrm{t}}\right)$ (Fig. 7) indicates that a large 

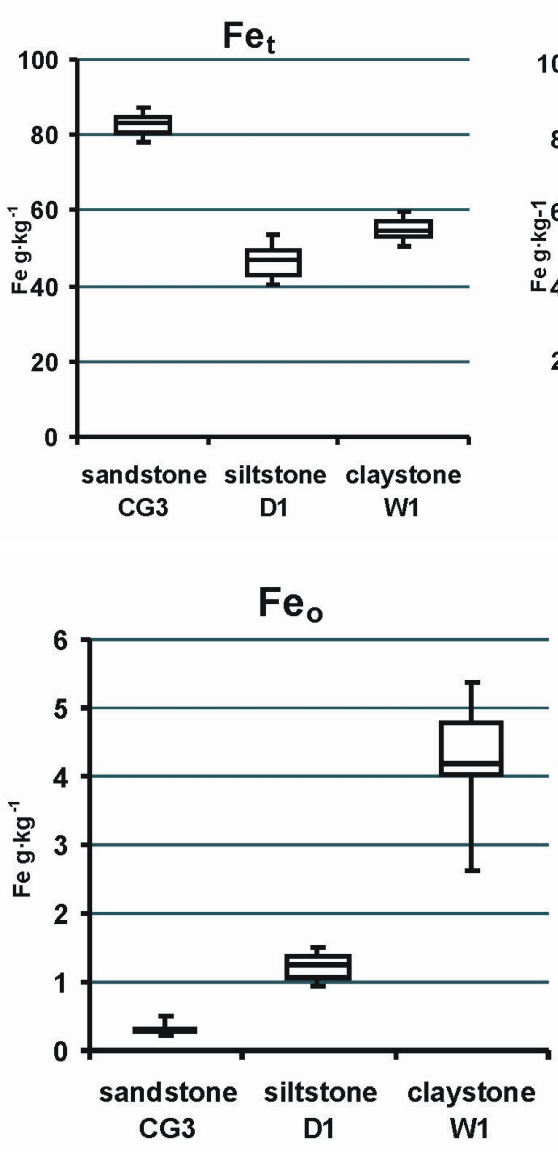

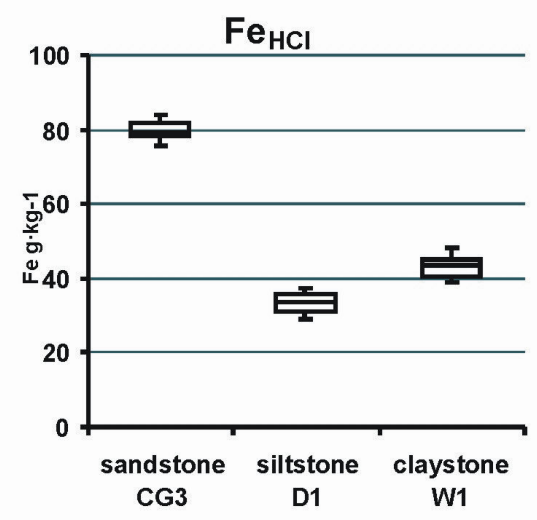

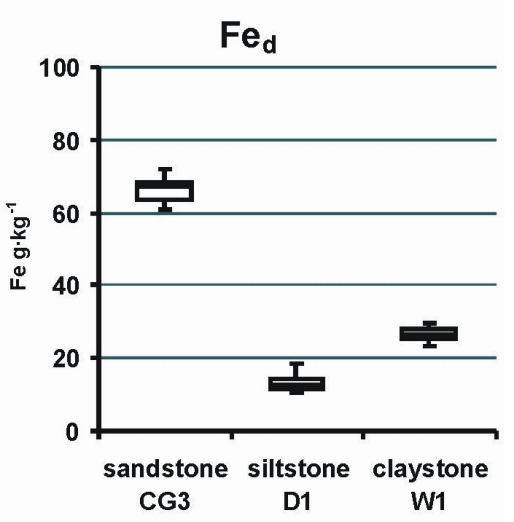

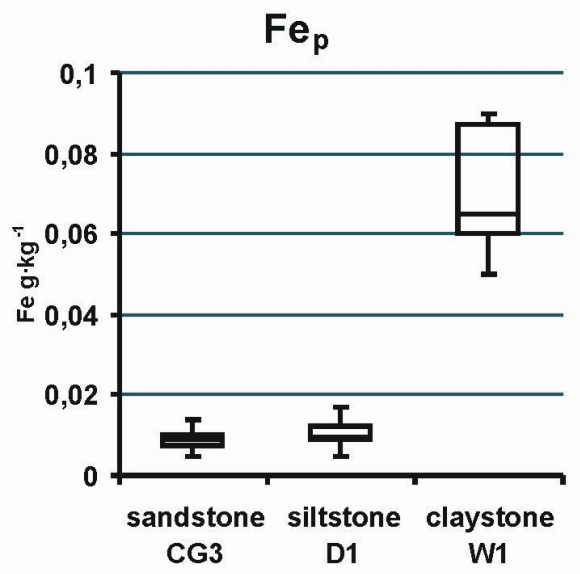

FIGURE 7. Comparison of the content of $\mathrm{Fe}$ forms in various rocks of the Buntsandstein formation in the NE Holy Cross Mountains

part of iron from the analysed Triassic rocks is permanently bound in the minerals. To assess this statement, iron was extracted in a stronger reagent such as hydrochloric acid (Sidhu et al. 1981, Schwertmann 1991). In sandstones CG3, the content of $\mathrm{Fe}_{\mathrm{HCl}}$

TABLE 3. Correlation coefficients between Fe forms in sandstone of the Buntsandstein formation in the NE Holy Cross Mountains Czerwona Góra (CG3)

\begin{tabular}{llllll}
\hline & $\mathrm{Fe}_{\mathrm{t}}$ & $\mathrm{Fe}_{\mathrm{HCl}}$ & $\mathrm{Fe}_{\mathrm{d}}$ & $\mathrm{Fe}_{\mathrm{o}}$ & $\mathrm{Fe}_{\mathrm{p}}$ \\
\hline $\mathrm{Fe}_{\mathrm{t}}$ & 1 & & & & \\
\hline $\mathrm{Fe}_{\mathrm{HCl}}$ & $0.8808^{*}$ & 1 & & & \\
\hline $\mathrm{Fe}_{\mathrm{d}}$ & -0.3770 & -0.1541 & 1 & & \\
\hline $\mathrm{Fe}_{\mathrm{o}}$ & -0.0697 & -0.3785 & -0.2635 & 1 & \\
\hline $\mathrm{Fe}_{\mathrm{p}}$ & 0.1583 & -0.0474 & -0.1562 & 0.2309 & 1 \\
\hline
\end{tabular}

TABLE 4. Correlation coefficients between $\mathrm{Fe}$ forms in siltstone of the Buntsandstein formation in the NE Holy Cross Mountains. Dziurów (D1)

\begin{tabular}{llllll}
\hline & $\mathrm{Fe}_{\mathrm{t}}$ & $\mathrm{Fe}_{\mathrm{HCl}}$ & $\mathrm{Fe}_{\mathrm{d}}$ & $\mathrm{Fe}_{\mathrm{o}}$ & $\mathrm{Fe}_{\mathrm{p}}$ \\
\hline $\mathrm{Fe}_{\mathrm{t}}$ & 1 & & & & \\
\hline $\mathrm{Fe}_{\mathrm{HCl}}$ & $0.7410^{*}$ & 1 & & & \\
\hline $\mathrm{Fe}_{\mathrm{d}}$ & 0.1298 & 0.2313 & 1 & & \\
\hline $\mathrm{Fe}_{\mathrm{o}}$ & 0.4533 & -0.0372 & 0.4302 & 1 & \\
\hline $\mathrm{Fe}_{\mathrm{p}}$ & 0.1429 & -0.3041 & 0.1693 & 0.5132 & 1 \\
\hline
\end{tabular}

TABLE 5. Correlation coefficients between Fe forms in claystone of the Buntsandstein formation in the NE Holy Cross Mountains. Wąchock (W1)

\begin{tabular}{llllll}
\hline & $\mathrm{Fe}_{\mathrm{t}}$ & $\mathrm{Fe}_{\mathrm{HCl}}$ & $\mathrm{Fe}_{\mathrm{d}}$ & $\mathrm{Fe}_{\mathrm{o}}$ & $\mathrm{Fe}_{\mathrm{p}}$ \\
\hline $\mathrm{Fe}_{\mathrm{t}}$ & 1 & & & & \\
\hline $\mathrm{Fe}_{\mathrm{HCl}}$ & $0.6645^{*}$ & 1 & & & \\
\hline $\mathrm{Fe}_{\mathrm{d}}$ & 0.0702 & 0.1371 & 1 & & \\
\hline $\mathrm{Fe}_{\mathrm{o}}$ & -0.1718 & -0.1979 & 0.4093 & 1 & \\
\hline $\mathrm{Fe}_{\mathrm{p}}$ & 0.2151 & 0.4007 & $0.6199^{*}$ & 0.1531 & 1 \\
\hline
\end{tabular}

is similar to the content of total iron - ca. $80 \mathrm{~g} \cdot \mathrm{kg}^{-1}$ (Fig. 7). In the remaining rocks, its contribution is lower and amounts $33 \mathrm{~g} \cdot \mathrm{kg}^{-1}$ in siltstones D1, and 44 $\mathrm{g} \cdot \mathrm{kg}^{-1}$ in claystones. The performed statistical analysis between particular $\mathrm{Fe}$ forms in the rocks studied revealed a significant correlation only between $\mathrm{Fe}_{\mathrm{HCl}}$ and $\mathrm{Fe}_{\mathrm{t}}$ (Table 3, 4, and 5).

\section{DISCUSSION}

\section{Pedogenic interpretation of the results}

The obtained results should be discussed in the context of specific properties of the rocks studied and the pedogenic process. The results of mineralogical and chemical studies indicate that the Lower Triassic 
rocks occurring in the eastern part of the Holy Cross Mountains area have a specific mineralogical and geochemical characteristics. The performed investigations indicate that the presence of Fe oxides plays the most important role in shaping soil properties. XRD analysis shows that both hematite and goethite occur in the rocks studied (Fig. 3). The presence of such iron minerals is characteristic of all red continental deposits (Torrent and Schwertmann 1986; Turner 1980, Lesovaya et al. 2005). The Buntsandstein strata from the eastern part of the Holy Cross Mountains area belong to such rocks (Mader and Rdzanek 1985; Ptaszyński and Niedźwiedzki 2006). Iron in the rocks studied is derived from various mineralogical sources. In sandstones CG3 it is derived from goethite. As indicated by detailed microscopic observations, goethite is a component of the matrix in Lower Triassic sandstones from the vicinity of Czerwona Góra (Barczuk 1979). In the case of siltstones from Dziurów and claystones from Wachock, the source of iron is hematite. Usually in red-coloured rocks, this mineral is a detritic component randomly distributed among quartz grains and clay minerals (Studencki 1993, Van Houten 1973, Torrent and Schwertmann 1986; Schwertmann 1993). For the assessment of progressive soil-forming processes significant is the lack of other iron minerals - e.g. magnetite or ferrihydrite.

Pedogenic interpretation requires tracing relationships between particular Fe chemical forms. They are well expressed in numerical proxies calculated with the use of analytical data (Fig. 8 and 9). Some of them attain characteristic values that may be considered as typical for the Lower Triassic rocks studied.

The most important is the $\mathrm{Fe}_{\mathrm{d}}: \mathrm{Fe}_{\mathrm{t}}$ proxy (Fig. 8), representing the degree of iron release (MacKeague and Day 1966; Zagórski 2001). It is used to assess the degree of susceptibility of the soil substrate to transformations taking place in the soil environment (Schwertmann 1988). It is generally assumed that the high contribution of free forms (high value of $\mathrm{Fe}_{\mathrm{d}}: \mathrm{Fe}_{\mathrm{t}}$ ) indicates significant Fe mobility in the soil. Mobilisation of iron may take place following the change of reaction to acidic or when redox processes are intensified after intervals with variable humidity (Schwertmann 1991, Cornell and Giovanoli 1993; Różański
FIGURE 8. Variability of ratios $\mathrm{Fe}_{\mathrm{d}}: \mathrm{Fe}_{\mathrm{t}}$ and $\mathrm{Fe}_{\mathrm{o}}: \mathrm{Fe}_{\mathrm{d}}$ in various rocks of the Buntsandstein formation in the NE Holy Cross Mountains

FIGURE 9. Relations between the ratios $\mathrm{Fe}_{\mathrm{d}}: \mathrm{Fe}_{\mathrm{t}}$ and $\mathrm{Fe}_{\mathrm{o}}: \mathrm{Fe}_{\mathrm{d}}$ in various rocks of the Buntsandstein formation in the NE Holy Cross Mountains
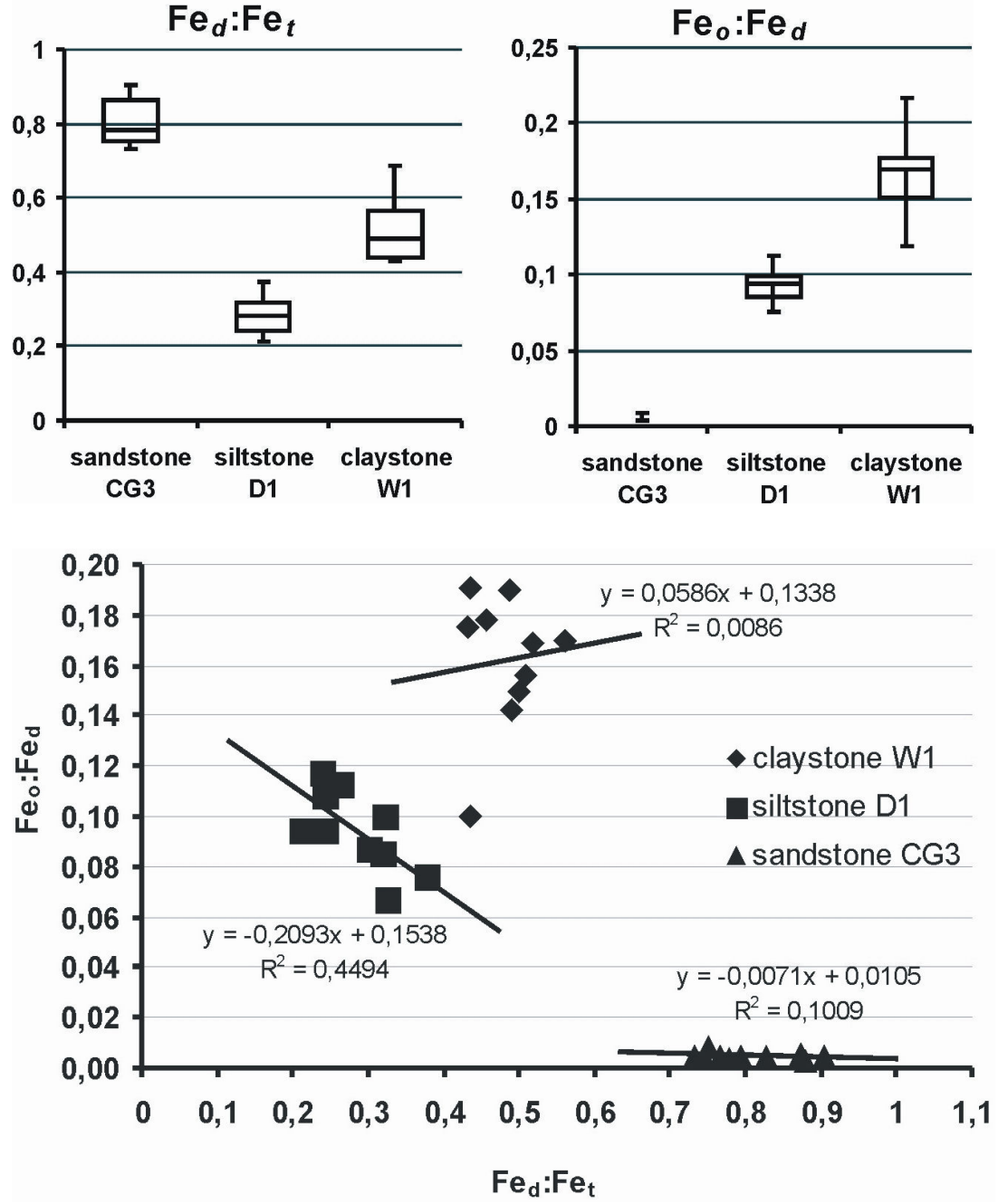
et al. 2013). In the rocks studied, the generally low value of $\mathrm{Fe}_{\mathrm{d}}: \mathrm{Fe}_{\mathrm{t}}$ indicates that potential release of iron in the pedogenic process will be restricted (Fig. 8 and 9). The reasons for this may lie in the origin of the sediment and in the high crystallinity of iron minerals, originated in specific conditions of long-term diagenetic processes. Sandstones from Czerwona Góra were formed from alluvial sediments characterised by various grain-size fractions, bound with a $\mathrm{Fe}$ oxide-carbonate cement. Specific geochemical conditions during sedimentation (moderately warm climate) (Mader and Barczuk 1985) and during later diagenesis caused that the main iron mineral is goethite. It forms a fine-crystalline cement with calcite (Barczuk 1979). The low value of the iron release proxy $\mathrm{Fe}_{\mathrm{d}}: \mathrm{Fe}_{\mathrm{t}}$ observed in the Czerwona Góra sandstones is probably linked with the fact that during extraction, goethite crystals are not easily available to the destructive factors of the reagents (e.g. DCB).

As evidenced by the studies, the solubility of goethite in sandstone increases significantly e.g. after chemical destruction of the rock. This is shown by the $\mathrm{Fe}_{\mathrm{HCl}}: \mathrm{Fe}_{\mathrm{t}}$ proxy (not shown). Its high value (0.98) indicates that destruction of the $\mathrm{Fe}$ oxide-calcareous cement in the sandstone by decomposition of calcite by $\mathrm{HCl}$ causes also the dissolution of goethite. Fine-crystalline goethite is easily soluble not only in $\mathrm{HCl}$, but also in sodium dithionite (Cornell et al. 1975). This phenomenon may have large significance for the course of pedogenic processes in the Czerwona Góra sandstones. The authors believe that during long-term pedogenesis, decomposition and allocation of carbonates takes place, resulting in physical and chemical disintegration of the sandstone. Decomposition of goethite is thus possible (Schwertmann 1991). Iron released from goethite will be active in the soil environment, which may be recorded in Fe-humus or $\mathrm{Fe}$ oxide-clay complexes during brownification processes. As a result, soils with cambic horizons develop, which leads to the formation of rich, eutrophic brown soils (Cambisols).

In the case of siltstones from Dziurów and claystones from Wachock, the low value of the iron release proxy $\mathrm{Fe}_{\mathrm{d}}: \mathrm{Fe}_{\mathrm{t}}$ (Fig. 8) results from different factors. This is related mostly with different mineralogical form of $\mathrm{Fe}$ oxide - hematite. Another factor influencing the low value of the $\mathrm{Fe}_{\mathrm{d}}: \mathrm{Fe}_{\mathrm{t}}$ proxy (Fig. 8) is the crystallinity of hematite in the rocks studied. Only the part of this material which is dispersed as nanocrystals within the clay fraction undergoes dissolution by DCB (Cornell and Giovanoli 1993). The presence and properties of hematite result from the specific origin of sediments from Dziurów and
Wąchock. The deposits represent continental settings in a warm and dry climate that prevailed during the sedimentation of the Upper Buntsandstein - Röt (Kleczkowski 1970). Large amounts of hematite developed in effect of weathering processes. Its detritic form is of large importance - it often occurs in concretions or oolites of various size (Kleczkowski 1970, Studencki 1993). Large resistance of hematite occurring in the rocks studied was additionally confirmed by the relatively low value of the $\mathrm{Fe}_{\mathrm{HCl}}: \mathrm{Fe}_{\mathrm{t}}$ proxy (not shown) in the range of 0.6-0.7. In other rock types, e.g. igneous rocks, the low value of this proxy is interpreted as evidence of the presence of iron in silicate and/or aluminosilicate minerals resistant to weathering (Schwertmann and Taylor 1989). Results of XRD analysis excluded the presence of such minerals in the rocks studied, apart from admixture of chlorite. The small difference in the values of $\mathrm{Fe}_{\mathrm{HCl}}: \mathrm{Fe}_{\mathrm{t}}$ and $\mathrm{Fe}_{\mathrm{d}}: \mathrm{Fe}_{\mathrm{t}}$ proxies indicates that hematite probably occurs in siltstones in larger grains than in claystones. The presence of hematite as the main source of iron has its consequences in the properties of soils developed on rocks representing the Röt. Low degree of iron release does not influence the enhancement of sorption properties of these soils; these properties are low due to the domination of kaolinite among the clay minerals (Brzychcy and Zagórski 2009). A practical effect of this feature is low fertility of the soils. Dispersed hematite stabilizes a compact, lithogenic structure of the soils, due to which they become difficult for cultivation (Schwertmann and Kämpf 1985). The macroscopic measure of the presence of hematite in soils from Wąchock and Dziurów is their stable red colour. According to Schwertmann (1993), hue 10R (following the Munsell Soil Color Charts 2009) points to the presence of this mineral. Torrent and Schwertmann (1986) concluded that the colour effect is visible at a very low content of hematite in rocks and soils.

The value of the proxy recording the content of amorphous $\mathrm{Fe}$ forms $\left(\mathrm{Fe}_{\mathrm{o}}: \mathrm{Fe}_{\mathrm{d}}\right)$ is very characteristic for the rocks studied (Fig. 8). Generally it is very low, but also quite variable between particular lithological types of the rocks studied. The significance of this proxy for pedogenesis is related with assessment of the degree, at which pedogenic processes generate the formation of secondary Fe oxides in the soil environment. Mineralogically these forms include poorly crystalline phases such as ferrihydrite, schwertmannite, sometimes green rust (fougerite) (Stucki et al. 2012, Vithana et al. 2015). XRD analyses have excluded the presence of such minerals (Fig. 3). The $\mathrm{Fe}_{\mathrm{o}}: \mathrm{Fe}_{\mathrm{d}}$ proxy was used to assess the susceptibility of $\mathrm{Fe}$ oxides to the dynamic influence of the soil envi- 
ronment, e.g. in variable redox conditions. DXRD analysis has indicated that both goethite and hematite occurring in the rocks studied are resistant to factors causing amorphousness of iron (Fig. 5). The small amount of amorphous Fe forms may be related to the decomposition of chlorites occurring in the rocks, particularly their ferruginous variants as shown by $\mathrm{DXRD}_{\mathrm{ox}}$ analysis (Fig. 6). The increase of $\mathrm{Fe}_{\mathrm{o}}$ values in the claystones from Wachock may be linked with this effect. Clearly, chlorite occurring in the claystones and siltstones may also undergo destruction in the soil environment (Bain 1977). Faint traces of amorphism and Fe migration as grey-green gley patches can be observed macroscopically in these rocks.

The contribution of the Fe linked with organic matter $\left(\mathrm{Fe}_{\mathrm{p}}\right)$ is insignificant in the studied rocks. This is related to the lack of organic matter in the rocks. According to Marynowski et al. (2002) the warm climate conditions prevailing during the Early Triassic in the Holy Cross Mountains area did not favour the accumulation of organic matter or caused its decline. This is also an important proxy that there is no lithogenic source of organic carbon in the substrate of soils developed on Lower Triassic rocks, contrary to soils developed on sandstones and claystones of flysch formations in the Carpathians (Urnug 1963).

\section{SUMMARY}

The presented research results confirm the thesis that the identification of the mineralogical and chemical properties of iron oxides is important in determining the genesis, typology and utility properties of soils and parent rocks with a characteristic red colour. Specific continental environmental conditions in which sediments were formed and subsequent diagenetic processes caused that the rocks of the Lower Triassic in the NE Holy Cross Mountains contain goethite or hematite.

The distribution of various chemical forms of iron $\left(\mathrm{Fe}_{\mathrm{t}}, \mathrm{Fe}_{\mathrm{HCl}}, \mathrm{Fe}_{\mathrm{d}}, \mathrm{Fe}_{\mathrm{o}}\right.$, and $\left.\mathrm{Fe}_{\mathrm{p}}\right)$ indicates that in subsequent processes, rock containing goethite will be more susceptible to pedogenic changes than those in which hematite occurs. The petrographic characteristics of rocks (sandstone, siltstone, claystone) are of great importance for soil-forming processes. In sandstones, the prior chemical destruction of the Fe oxide-calcareous cement greatly accelerates the degradation of goethite and the release of free iron. In siltstones and claystones, the release of iron is difficult due to the high resistance to weathering of detrital hematite grains. The formation of amorphous forms may be favoured by the destruction of chlorites contained in the clay fraction. Similar facies of the rocks studied and those of the Lower Triassic deposits from other parts of the Holy Cross Mountains allows to assume that the analytical data obtained and conclusions drawn may be applied to soils developed in similar conditions. Therefore, studies should be continued on a wider area and in a wider analytical range. The authors hope that the obtained results will enrich knowledge on the specific and unique character of rocks developed from red beds in Poland and other parts of the world.

\section{ACKNOWLEDGMENTS}

Research was supported by the Polish Ministry of Science and Higher Education, project No 2P04G10728.

\section{REFERENCES}

Bain D.C., 1977. The weathering of ferruginous chlorite in a podzol from Argyllshire, Scotland. Geoderma 17: 193-208.

Barczuk A., 1979. Petrographic study of the Buntsandstein sediments from the North-Eastern border of the Holy Cross Mts (Central Poland). Archiwum Mineralogiczne 35(2): 87-155.

Brindley G.W., Brown G., 1980. Crystal structures of clay minerals and their x-ray identification. Mineralogical Society, London: 494 pp.

Brzychcy S., Zagórski Z., 2009. Kaolinite - as an indicator of lithogenetic process in soils developed from Lower Triassic sediments in the Holy Cross Mountains. Roczniki Gleboznawcze - Soil Science Annual 60(4): 104-112.

Beckhoff B., Kanngießer B., Langhoff N., Wedell R., Wolff H., 2007. Handbook of Practical X-Ray Fluorescence Analysis. Springer Science \& Business Media, Berlin: 863 pp.

Campbell A.S., Schwertmann U., 1985. Evaluation of selective dissolution extractants in soil chemistry and mineralogy by differential X-Ray diffraction. Clay Minerals 20: 515-519.

Cornell R.M., Giovanoli R., 1993. Acid solution of hematites of different morphologies. Clay Minerals 28: 223-232.

Cornell R.M., Posner A.M., Quirk J.P., 1975. The complete dissolution of goethite. Journal of Applied Chemistry and Biotechnology 25: 701-706.

Cornell R.M., Schwertmann U., 2006. The iron oxides: structure, properties, reactions, occurrences and uses. Wiley\&Co, Weinheim: 703 pp.

Costantini E.A.C., Lesovaya S.N., Vodyanitskii Y.N., 2006. Using the analysis of iron and iron oxides in paleosols (TEM, geochemistry and iron forms) for the assessment of present and past pedogenesis. Quaternary International 156: 200-211.

Curi N., Franzmeier D.P., 1987. Effect of parent rocks on chemical and mineralogical properties of some oxisols in Brasil. Soil Science Society of America Journal 51: 153-158.

Filonowicz P., 1968. Explanations to the Detailed Geological Map of Poland 1:50 000, sheet Słupia Nowa. Wydawnictwa Geologiczne, Warszawa: 73 pp.

Gedrojć K., 1955. Chemiczeskij analiz poczwy. Moskwa: 156 pp.

Hamer M., Graham R.C., Amrhein C., Bozhilov K.N., 2003. Dissolution of ripidolite ( $\mathrm{Mg}, \mathrm{Fe}$-chlorite) in organic and inorganic acid solutions. Soil Science Society of America Journal 67(2): 654-661. 
Kleczkowski A., 1970. Iron ores in the Bunter deposits of the northern margins of the Góry Świętokrzyskie. Prace Muzeum Ziemi 15(1): 193-221.

IUSS Working Group WRB, 2015. World Reference Base for Soil Resources 2014, update 2015. International soil classification system for naming soils and creating legends for soil maps. World Soil Resources Reports 106, FAO, Rome: 192 pp.

Lesovaya S.N., Goilo E.A., Chizhikova N.P., 2005. Mineralogical composition of red-Earth deposits and its effect on soil formation in the northern Taiga of European Russia. Eurasian Soil Science 38(8): 887-896.

Loveland P.J., Digby P., 1984. The extraction of Fe and Al by 0.1 M pyrophosphate solutions: a comparison of some techniques. European Journal of Soil Science 35(2): 243-250.

MacKeague J.A., Brydon J.E. Miles N.M., 1971. Differentiation of forms of extractable iron and aluminium in soils. Soil Science Society of America, Proceedings 35: 33-38.

MacKeague J.A., Day J.H., 1966. Dithionite- and oxalate extractable $\mathrm{Fe}$ and $\mathrm{Al}$ as aids in differentiating various classes of soils. Canadian Journal of Soil Science 46(1): 13-22.

Mader D., Barczuk A., 1985. Gravelly to sandy braidplain deposition in the Czerwona Góra Beds and Stryczowice Beds (Middle Buntsandstein) of the Northeastern Holy Cross Mountains (Poland). [In:] Aspects of fluvial sedimentation in the Lower Triassic Buntsandstein of Europe. (Mader D., Editor), Springer-Verlag Berlin Heidelberg 4: 351-396.

Mader D., Rdzanek K., 1985. Sandy braidplain deposition with minor pedogenesis in the labyrinthodontidae beds (middle buntsandstein) of the northeastern holy cross mountains (Poland). [In:] Aspects of fluvial sedimentation in the Lower Triassic Buntsandstein of Europe. (Mader D., Editor), Springer-Verlag Berlin Heidelberg 4: 281-317.

Marynowski L., Salamon M., Narkiewicz M., 2002. Thermal maturity and depositional environments of organic matter in the post-Variscan succession of the Holy Cross Mountains. Geological Quarterly 46(1): 25-36.

Mehra O.P., Jackson M.L.,1960. Iron oxide removal from soils and clays by a dithionite-citrate system buffered with sodium bicarbonate. Clays and Clay Minerals 7: 317-327.

Munsell Soil Color Charts, 2009. Munsell Color Co. Inc. Baltimore 18, Maryland 21218, USA.

Pansu M., Gautheyrou J., 2006. Handbook of Soil Analysis Mineralogical, organic and inorganic methods. Springer-Verlag Berlin Heidelberg: 993 pp.

Polish Soil Classification (Systematyka gleb Polski), 2011. Roczniki Gleboznawcze - Soil Science Annual 62(3): 1-193.

Ptaszyński T., Niedźwiedzki G., 2006. Buntsandstein in the Holy Cross Mountains: chronostratigraphy and lithostratigraphical correlation with the Thuringian Basin. Przegląd Geologiczny 54(6): 525-533.

Ross G.J., 1968. Structural decomposition of orthochlorite during its acid dissolution. The Canadian Mineralogist 9(4): 522-530.

Różański S., Bartkowiak A., Jaworska H., 2013. Forms of iron as an indicator of pedogenesis in profiles of selected soil types of the northern area of kujawsko-pomorskie province, Poland. Roczniki Gleboznawcze - Soil Science Annual 64(3): 98-105.

Samsonowicz J., 1932. Explanations to the Detailed Geological Map of Poland 1:50 000, sheet Opatów. Instytut Geologiczny, Warszawa: $73 \mathrm{pp}$.
Schulze D.G., 1981. Identification of soil iron oxide minerals by differential X-ray diffraction. Soil Science Society of America 45: 437-440.

Schulze D.G., 1994. Differential x-ray diffraction analysis of soil minerals. [In:] Quantitative methods in soil mineralogy (Amonette J.E., Zelazny L.W., Editors). Soil Science Society of America: 412-428.

Schwertmann U., 1988. Occurrence and formation of iron oxides in various pedoenvironments. [In:] Iron in soils and clay minerals (Stucki J.W., Goodman B.A., Schwertmann U., Editors). Springer Netherlands: 267-308.

Schwertmann U., 1991. Solubility and dissolution of iron-oxides. Plant and Soil 130: 1-25.

Schwertmann U., 1993. Relations between iron oxides, soil color and soil formation. [In:] Soil Color (Bigham J.M., Ciołkosz E.J., Editors), Soil Science Society of America, Special Publication 31, Wiley, Madison: 51-69.

Schwertmann U., Kämpf, N., 1985. Properties of goethite and hematite in kaolinitic soils of Southern and Central. Brazil. Soil Science 139(4): 344-350.

Schwertmann U., Taylor R.M., 1989. Iron oxides. [In:] Minerals in soil Environments (Dixonand J.B.,. Weed S.B., Editors) Soil Science Society of America, Madison, WisconsinUSA: 379-438.

Senkowiczowa H., Ślączka A., 1962. On the age of the Wąchock sandstone. Roczniki Gleboznawcze - Soil Science Annual 32: 313-337.

Senkowiczowa H., 1966. Influence of palaeozoic structure and of morphology of the Święty Krzyż Mts. area upon the development of Triassic deposits. Geological Quarterly 10(4): 986-1002.

Sidhu P.S., Gilkes R.M., Cornell J.R., Posner A.M., Quirk J.P., 1981. Dissolution of iron oxides and oxyhydroxides in hydrochloric and perchloric acids. Clays and Clay Minerals 29(4): 269-276.

Stucki J.W., Goodmann B.A., Schwertmann U., 2012. Iron in soils and clay minerals. Springer Netherlands: $894 \mathrm{pp}$.

Studencki M., 1993. Explanations to the Detailed Geological Map of Poland 1:50 000, sheet Starachowice. Wydawnictwa Geologiczne, Warszawa: $87 \mathrm{pp}$.

Tamm O., 1934. Über die oxalat-methode in der chemischen Boden analyse. Medd. Skogförsökamsanst, 27: 1-20.

Torrent J., Schwertmann U., Schulze D.G., 1980. Iron oxide mineralogy of some soils of two river terrace sequences in Spain. Geoderma 23(3): 191-208.

Torrent J., Schwertmann U., 1986. Influence of hematite on the color of red beds. Journal of Sedimentary Petrology 57(4): 682-686.

Turner P., 1980. Continental red beds. Developments in sedimentology. Elsevier, Amsterdam (29): 561 pp.

Urnug R., 1963. Istebna Beds - a fluxoturbidity formation in the Carpathian Flysch. Annales Societatis Geologorum Poloniae 33(1): 49-98.

Wyszomirski P., Muszyński M., 2007. Charakterystyka mineralogiczno-surowcowa przerostów i wtrąceń w czerwonych kopalinach ilastych triasu północnego obrzeżenia Gór Świętokrzyskich. Gospodarka Surowcami Mineralnymi 23(1): 5-28.

Van Houten F.B., 1973. Origin of red beds. A review - 19611972. Annual Review of Earth and Planetary Sciences (1): 39-61. 
Vithana C.L., Sullivan L.A., Bush R., Burton E.D, 2015. Schwertmannite in soil materials: Limits of detection of acidified ammonium oxalate method and differential X-ray diffraction. Geoderma 249-250: 51-60.

Vodyanitskii Y.N., Goryachkin S.V., Lesovaya S.N., 2003. Iron oxides in burozems on red-colored deposits in European Russia and the color differentiation of soils. Eurasian Soil Science 36(11): 1145-1158.

Vodyanitskii Y.N., 2010. Iron hydroxides in soils: A review of publications. Eurasian Soil Science (43): 1244-1254.

Walker T.R., 1968. Formation of red beds in modem and ancient deserts: Reply. Geological Society of America Bulletin (79): 281-282.

Zagórski Z., 2001. Iron forms as indicators of pedo-and lithogenetic processes in non-uniform soils. Roczniki Gleboznawcze - Soil Science Annual 52: 87-96.

Zagórski Z., Kaczorek D., 2002. Haematite - a lithogenic form of iron in soils from the southern part of the Holy Cross Mountains. Annales of Warsaw Agricultural UniversitySGGW 43(200): 17-24.
Zagórski Z., Kisiel M., 2010. Lepidocrocite as mineralogical indicator of gley processes in soils formed on Lower Triassic sediments in the Holy Cross Mountains - Roczniki Gleboznawcze - Soil Science Annual 61(1): 77-87.

Zagórski Z., Kisiel M., 2014. Soils developed from red clays of the Lower Triassic in the north-western part of the Świętokrzyskie Mountains. [In:] Soil sequences atlas (Świtoniak M., Charzyński P., Editors), Wydawnictwo Uniwersytetu Mikołaja Kopernika, Toruń: 141-153.

Zagórski Z., Kisiel M., Kuśmierz A., 2015. Selected properties and systematic position of soils developed from red sandstones and clays of the Lower Triassic Buntsandstein in the NW part of the Holy Cross Mountains (Poland). Roczniki Gleboznawcze - Soil Science Annual 66(3): 139-153.

Received: December 13, 2018

Accepted: January 31, 2019

Associated editor: t. Uzarowicz

\section{Formy żelaza w skałach macierzystych gleb wytworzonych z osadów dolnego triasu (piaskowca pstrego) w pólnocno-wschodniej części Gór Świętokrzyskich}

\footnotetext{
Streszczenie: Celem badań była charakterystyka pedogenicznych form żelaza w osadach dolnego triasu (Buntsandstein) w północno-wschodniej części Gór Świętokrzyskich. Są to kontynentalne osady o unikatowych cechach znane jako „red beds”. Badane były trzy główne typy skał, tj.: piaskowce, mułowce i iłowce. Oznaczono chemiczne formy żelaza: $\mathrm{Fe}_{\mathrm{t}}(\mathrm{XRF}), \mathrm{Fe}_{\mathrm{HCl}}(6 \mathrm{MHCl}), \mathrm{Fe}_{\mathrm{d}}$ (DCB), $\mathrm{Fe}_{\mathrm{o}}$ (szczawian amonu), $\mathrm{Fe}_{\mathrm{p}}$ (pirofosforan sodu). Metodą dyfrakcji rentgenowskiej (XRD) stwierdzono występowanie getytu w piaskowcach oraz hematytu w mułowcach i iłowcach. Oprócz wymienionych minerałów, w skałach występował również kwarc, skalenie i minerały ilaste (kaolinit, illit, chloryt). Analiza DXRD nie wykazała obecności amorficznych minerałów żelaza. Przeciętna zawartość Fe ${ }_{\mathrm{t}}$ wynosiła w piaskowcach $83 \mathrm{~g} \cdot \mathrm{kg}^{-1}$, w mułowcach $47 \mathrm{~g} \cdot \mathrm{kg}^{-1}$, w iłowcach $55 \mathrm{~g} \cdot \mathrm{kg}^{-1}$. Znacznie mniej stwierdzono Fe (odpowiednio: $66 \mathrm{~g} \cdot \mathrm{kg}^{-1}, 13 \mathrm{~g} \cdot \mathrm{kg}^{-1}, 26 \mathrm{~g} \cdot \mathrm{kg}^{-1}$ ). Zawartość Fe była niewielka i mieściła się w przedziale od $0,3 \mathrm{do} 4 \mathrm{~g} \cdot \mathrm{kg}^{-1}$. $\mathrm{W}$ badanych skałach występowały śladowe ilości $\mathrm{Fe}_{\mathrm{p}}$. Dobrą korelację wykazały tylko zawartości $\mathrm{Fe}_{\mathrm{t}}$ i $\mathrm{Fe}_{\mathrm{HCl}}$. Przy interpretacji pedogenicznej badanych skał posłużono się wzajemnymi relacjami pomiędzy chemicznymi formami żelaza oraz ich odniesieniem do stwierdzonych minerałów żelaza. Mułowce i iłowce wykazują dużą odporność na czynniki pedogeniczne na co wskazują niskie wskaźniki uwolnienia $\mathrm{Fe}_{\mathrm{d}}: \mathrm{Fe}_{\mathrm{t}} \mathrm{i}$ bardzo niskie wskaźniki amorfizacji $\mathrm{Fe}_{\mathrm{o}}: \mathrm{Fe}_{\mathrm{d}}$. Przyczyną jest obecność w tych skałach dobrze wykrystalizowanego hematytu. W piaskowcach odporność jest uwarunkowana występowaniem getytu w spoiwie. Przeprowadzone badania wskazują że specyfika skał dolnego triasu jest ważna dla właściwej klasyfikacji i oceny właściwości gleb z charakterystyczną czerwoną barwą.
}

Słowa kluczowe: formy żelaza, hematyt, getyt, skały macierzyste, trias (pstry piaskowiec) 